\title{
Justiça Juvenil / Juvenile Justice
}

https://doi.org/10.21814/uminho.ed.36.40

\section{Chandni Basu}

Institute of Sociology, University of Freiburg, Germany \& Institute of Development Studies Kolkata, India 



\section{Justiça Juvenil}

Os sistemas de justiça juvenil e de proteção de crianças constituem os dois lados da mesma moeda. O Direito moderno, enquanto dispositivo do Estado, funciona como mecanismo de controlo social, dada a importância da lei e do posicionamento ético-moral que lhe é inerente e, consequentemente, o seu impacto e influência na sociedade. 0 sistema de justiça juvenil, enquanto parte integrante das estruturas legais modernas, é orientado para a gestão do desvio de crianças em conflito com a lei, logo, o desvio na infância. Evidentemente, a justiça juvenil, é amplamente considerada como uma questão "legal". Em termos académicos, o desvio na infância é convencionalmente considerado relevante no âmbito de disciplinas do Direito, da Criminologia ou da Psicologia enquanto o interesse sociológico na justiça juvenil permanece especialmente significativo no âmbito dos Estudos sobre a Infância. Este facto faz incidir o foco sobre a prevenção da delinquência ou do crime na infância, o que constitui uma contradição no seio de uma conceção moderna da infância, baseada na inocência da criança.

Atualmente, um sistema de justiça juvenil, enquanto mecanismo legal independente para crianças em conflito com a lei [ ${ }^{*}$ ver conceito, p. 149] é estabelecido em cumprimento das orientações da Convenção sobre os Direitos da Criança, adotada pela Organização das Nações unidas em 1989, complementada pelas Regras Mínimas das Nações Unidas para a Administração da Justiça Juvenil, também designadas por Regras de Beijing (1985), e pelos Princípios Orientadores das Nações Unidas para a Prevenção da Delinquência Juvenil, conhecidos por Princípios de Riade (1990).

A justiça juvenil é baseada nos princípios de justiça restaurativa e atribui ao Estado o papel de parens patriae (em latim, significa "pai da nação"). Esta conceção da justiça juvenil é geradora de sobreposições entre Direito, infância, desvio e criminalidade, as quais perpassam a intertextualidade do social e do legal. O Direito é influenciado pelas normas sociais, ao mesmo tempo que estabelece padrões sociais por meio das decisões de jurisprudência. Assim sendo, uma distinção entre os domínios do legal e do social será tão improvável como desnecessária, na medida em que "não existe um dentro e um fora da lei" (Cotterrell, 2003, p. 257). E, no entanto, as esferas do legal e do social existem como espaços textuais distintos e validados 
por sistemas, processos e instituições próprios, como disso é exemplo o dispositivo de justiça juvenil.

O princípio de justiça restaurativa visa proporcionar proteção a crianças menores de idade apanhados no escopo da lei. Sustenta-se no princípio de mens rea (em latim, significa "mente culpada"), importante conceito na legislação que envolve as crianças em conflito com a lei. Esta conceção traduz-se, no âmbito da política criminal, na priorização da idade de responsabilidade criminal como indicador da "intenção de cometer um crime". Assim, o envolvimento de crianças com a lei está limitado à esfera do direito criminal [ou equiparado a tal]. Em virtude da consideração da menoridade legal baseada na idade biológica, as crianças encontram-se impedidas de estabelecer acordos contratuais no âmbito do direito civil, excetuando os casos de divórcio dos pais que impliquem a separação das crianças de um dos progenitores. Por força das normas internacionais, após a resolução do processo num tribunal da jurisdição de família e de crianças e jovens, é eliminado o registo oficial reportado às suas práticas de factos qualificados pela lei penal como crime, bem como ao seu percurso. Uma diferença relativamente ao sistema penal que se justifica pela necessidade de proteção da infância.

Um breve olhar sobre a história revela as preocupações que estiveram na base de um sistema judicial específico para crianças menores de idade na forma do dispositivo de justiça juvenil. 0 Child Saving Movement ${ }^{8}$ ou o estabelecimento do primeiro tribunal de menores nos Estados Unidos da América, no século XIX, constituem importantes marcas históricas nesta direção (Platt, 1969), sendo que as bases das conceções e práticas contemporâneas de justiça juvenil podem ser encontradas nessas primeiras iniciativas. Surpreendentemente, a importância do imperialismo colonial do século XIX encontra expressão na história da justiça juvenil, nomeadamente através da conceção e administração da prisão e dos reformatórios na sociedade nativa por parte da administração colonial, tanto em termos da jurisprudência moderna como da gestão penal. Uma ligação estreita entre a criança e a colónia esteve na base destas conceções e práticas. Deste modo, a narrativa do imperialismo colonial influenciou a invenção da infância e da criança como ser singular. A missão de civilizar os nativos assemelhava-se à disciplinação da criança, fazendo parte dos esforços coloniais que concebiam os sujeitos nativos como inferiores/primitivos/infantis (Nandy, 1983). No

8 Movimento que surgiu no século XIX, nos Estados Unidos da América, tendo impulsionado o desenvolvimento do sistema de justiça juvenil. 
âmbito do sistema judicial-penal da administração colonial, focado na criança nativa delinquente, sobretudo proveniente das margens sociais, a justiça juvenil revelou-se importante em termos da gestão da criança e do desvio na sociedade nativa. De forma significativa, atualmente, crianças e detidos pertencem, na sua maioria, a posições sociais marginalizadas. O número especialmente representativo de casos oficialmente registados de justiça juvenil provenientes de espaços socialmente desfavorecidos em qualquer parte do mundo aumenta a contestação pós-colonial na justiça juvenil. A adoção de uma lente pós-colonial sobre esta matéria é importante, não só como ferramenta metodológica, mas também pela relevância para evitar erros epistémicos crescentes no modo como lidamos, no campo da justiça juvenil, com crianças e jovens colocados nas margens da sociedade; erros que, de outro modo, ameaçam aumentar.

(Tradução de Ana Manso)

\section{Juvenile Justice}

Juvenile justice and child protection are two sides of the same coin. Modern law as an apparatus of the state mechanism functions as the domain of social control. This relates to the importance of law in terms of its inherent ethical and moral stance, and thereby its impact and influence on society. The juvenile justice system as part of the modern legal structure is geared towards child/deviance management for children in conflict with the law. Deviance in childhood, and axiomatically juvenile justice too, is considered largely as a "legal" issue. It is deemed to be relevant for academic engagement conventionally within the disciplinary ambit of Law, Criminology or Psychology. A sociological concern of juvenile justice, however, remains especially significant within the parameters of Childhood Research. It brings to the foreground the contention of crime in childhood, which presents itself as an oxymoron within the scheme of an innocence- based conception of modern childhood. Now, the juvenile justice system, as a separate legal mechanism for apprehended young people, has been inaugurated in compliance with the United Nations Convention on the Rights of Children (UNCRC) 1989 guidelines, which is further complemented by the Beijing Rules (1985) and the Riyadh Guidelines (1990).

Juvenile justice is grounded on the principles of restorative justice and advances the role of the state as parens patriae (In Latin,"parent of the nation"). This concept of juvenile justice overlaps among Law, childhood, deviance, 
and criminality which pervade implies the inter-textuality of the social and the legal. Law is influenced by societal norms, as it also sets standards through its jurisprudential engagements. A distinction between the legal and the social realm is therefore not only improbable but unnecessary, as "there is no single inside or outside of law" (Cotterrell, 2003, p. 257). The spheres of the legal and the social, however, exist as distinguishable textual grounds validated through particular systems, processes and institutions, like the mechanism of juvenile justice.

The principle of restorative justice aims to provide protection to apprehended children within the purview of law. It upholds mens rea (In Latin, guilty mind) as a significant concept in the jurisprudence of criminal offences involving children in conflict with the law. This translates to the prioritization of the age of criminal responsibility in terms of denoting "intention of committing a crime" within criminal jurisprudence. Children's engagement with law is limited to the sphere of criminal law. Owing to the consideration of biological age- based legal minority, young people are prohibited from entering contractual agreements within the domain of civil law, barring exceptions as in divorce cases among parents involving the separation of children from one parent. Juvenile justice translates into providing the advantage of non-declaration of criminal records for the children in conflict with the law after the disposal of cases at the juvenile justice boards.

A brief look at history highlights the concern with delinquency which led to the conception of a separate judicial-penal system for legal minors in the form of the juvenile justice mechanism. The Child Saving Movement or the setting up of the first juvenile court in the United States of America in the nineteenth century remains historically significant in this direction (Platt, 1969). Foundations of contemporary notions and practices of juvenile justice could be traced to such initiatives. Notably, the significance of imperialist colonialism in the nineteenth century remains paramount in the history of juvenile justice. This is related to the conception and administration of prison and reformatories in native society both in terms of modern jurisprudence and penal management by the colonial administration. A close link between the child and the colony informed these conceptions and practices. The narrative of colonial imperialism involved the invention of childhood and the figure of the singular child. The mission to civilise the "infantile natives" thus remained analogous with the disciplining of the child as part of the colonial endeavour, which imagined the native subjects as inferior/primitive/childlike (Nandy, 1983). Within the judicial-penal system of the colonial administration, focus on the delinquent native child 
mostly from marginal social locations also created the relevance of juvenile justice in terms of child/deviance management for native society. Significantly, in contemporary times, apprehended young people mostly belong to marginalized social positions. Recently, a growing number of reported cases of juvenile justice from disadvantaged social locations around the world raises the contention of the postcolonial in juvenile justice. A postcolonial lens is important not only as a methodological tool but also in terms of its ability to avoid epistemic errors which otherwise loom large in dealing with marginal young people within the legal scope of juvenile justice.

\section{Referências / References}

Cotterrell, R. (2003). Politics of Jurisprudence: A Critical Introduction to Legal Philosophy (2nd ed.). New Delhi: Oxford University Press.

Nandy, A. (1983). The Intimate Enemy: Loss and Recovery of Self under Colonialism. New Delhi: Oxford University Press.

Platt, A. (1969). The Rise of the Child-Saving Movement: A Study in Social Policy and Correctional Reform'. Annals of the American Academy of Political and Social Sciences, 381, 21-38. 